\title{
Culinary Nostalgia and Post-Traumatic Stress Disorder: Addenda to Kinga Király's Az újrakezdés receptjei (2019) / Recipes for a New Beginning (2020)
}

\author{
Louise O. Vasvári
}

\begin{abstract}
Kinga Király conducted interviews with ten North Transylvanian survivors who represent the last witnesses of a generation that is about to disappear and leave us with the question of what to remember and how. On reading the testimonies catalogued in the volume Király produced from those interviews, I realized that I felt compelled to make further connections with my own research on foodways and war trauma and on the ecologies of survival witnessing. In a section on the mass genocide of Transylvanian Jewry I provide a brief historical sketch to help the understanding of the historical complexity and tragedy of the lives of pre- and postwar Transylvanian Jewry. I then contrast the stories of some of Király's subjects with the postwar memoirs of other Transylvanian survivors who emigrated either right after the war or under the Ceausescu dictatorship. I discuss prewar Transylvanian Jewish food culture, and subsequently locate Király's collection as a continuation of the tradition of the memorial or yizkor ['remembrance'] books. Finally, I discuss Jewish cemeteries and the virtual social death of Jewish tradition in Transylvania, to ask: what is it that remains today from the shattered culture of Transylvanian Jewry?
\end{abstract}

Keywords: alimentary life writing, foodways, North Transylvanian Jewry, Proustian memory, social death, ecology of witnessing, yizkor books, Jewish cemeteries

Biography: Louise O. Vasvári (Ph.D., UC, Berkeley) is Professor Emerita of Comparative Literature and of Linguistics at Stony Brook University. Currently she teaches in the Linguistics Department at NYU and is also Affiliated Professor at the University of Szeged. She works in Medieval Studies, diachronic and sociolinguistics, Holocaust Studies, and Hungarian Studies, all informed by gender theory within a broader framework of Comparative Cultural Studies. In relation to Hungarian Cultural Studies she has published numerous articles, as well as, with Steven Tötösy, Imre Kertész and Holocaust Literature (2005), Comparative Central European Holocaust Studies (2009), and Comparative Hungarian Cultural Studies (2011). Since 2011 Vasvári is also Editorin-Chief of Hungarian Cultural Studies. louise.vasvari@stonybrook.edu 
Vasvári, Louise O. "Culinary Nostalgia and Post-Traumatic Stress Disorder: Addenda to Kinga Király's $A z$ újrakezdés receptjei (2019) / Recipes for a New Beginning (2020).” Hungarian Cultural Studies. e-Journal of the American Hungarian Educators Association, Volume 14 (2021): http://ahea.pitt.edu DOI: 10.5195/ahea.2021.437

\section{Introduction to Az újrakezdés receptjei (2019) / Recipes for a New Beginning (2020) and the Study of Foodways}

One day Kinga Király realized that except for cholent and flódni ('a Hungarian Jewish multi-layered poppy-seed, jam, walnut, and apple pastry'), she knew nothing about Transylvanian Jewish cuisine. So, she set out on a project to fulfill her own cravings for real flavor, but, more deeply, to learn about prewar recipes and customs and to find out what remained of kosher households of Northern Transylvania. She conducted some three hundred hours of participant-observer interviews over a year and a half - sometimes spiced with cooking sessions - with ten survivors who had experienced the Holocaust as teenagers or children and with whom she met in Northern Transylvania and Budapest. These survivors represent the absolute last witnesses of a generation that is about to disappear and leave us with the question of what to remember and how.

The results of the interviews appeared in 2019 as Az újrakezdés receptjei, Erdélyi zsidó történetek életröl, éhségröl és reménységröl, and the English translation appeared a year later, for which I was asked to write an introduction. On reading the testimonies catalogued in the volume I realized that I would feel compelled to make further connections with them with my own ongoing research than was possible within the confines of an introduction. My work on alimentary life writing has taught me about the importance of food talk, recipe notebooks, and memoirs that incorporate food descriptions, all of which can teach us a lot about their creators and the history of their religious or other ethos, social networks, tradition and culture. At the same time, it is also important to note that food talk as a storehouse of memories is not dependent on the happy childhood that is often invoked. Rather, such memories can recreate the fiction of one, with food used through nostalgic discourse to create an idealized time before a later insecure or dangerous time.

Anthropologists talk of the intricate relationship between food and eating habits and of food as one of many areas where a basic activity is invested with symbolic social meaning in both individual and collective memory. A major cultural function of food and eating is to link the individual to the social sphere, first through the mother and the family and then in relation to the larger social group. The flavor of prepared foods is humanity's greatest universal shared behavior. It is the power of the unconscious odor that dominates flavors, and flavor is among the most complex and powerful of all human sensations. Flavor perception is also closely linked in the human brain to systems for learning, memory, emotion, and language. The memory power of food derives in part from synesthesia, the crossing of experiences from different sensory registers. Such odor- and taste-evoked autobiographical memories have come to be known as the Proust phenomenon or Proustian memory, as Proust's protagonist in À la recherche du temps perdu depends on the subtle taste and smell of madeleines to recall the events of his past. Experiments have confirmed that such memories tend to be stronger, more emotional, and more effective reminders of past experiences originating from early life than memory cues from other senses. In 2010 an exhibit in the Jewish Museum in Camden, London attempted to make use of this culinary "olfactory experience" with the creation of a typical immigrant kitchen, from which the smells of chicken soup wafted across the museum. The stated purpose of the exhibition was the museum's aim of creating an olfactory archive within the human body, in order to aid in the experience of recollecting Jewish familial life via the olfactory sense.

While scent-cued food memories form an important component of nostalgic memory and of deep memory, they also bear a connection to post-traumatic stress disorder, and thus the study of foodways naturally intersects with the Holocaust. It is now becoming evident that a significant 
Vasvári, Louise O. "Culinary Nostalgia and Post-Traumatic Stress Disorder: Addenda to Kinga Király's $A z$ újrakezdés receptjei (2019) / Recipes for a New Beginning (2020).” Hungarian Cultural Studies. e-Journal of the American Hungarian Educators Association, Volume 14 (2021): http://ahea.pitt.edu DOI: 10.5195/ahea.2021.437

number of recipe collections also emerged out of wars. It is primarily a few female historians of the Holocaust who have studied the significance of war food talk and food writing as a survival strategy. In contrast, some male scholars, representing a tendency in Holocaust studies of perceiving a widespread commodification and sacralization of the Holocaust, have unjustly criticized the genre as kitsch. Holocaust recipe collections were compiled even in camps and slave labor factories during the war, as well as by postwar survivors. However, the only such memorial volume published in Hungarian that antedates Kiraly's work is Mrs. István Endrei, Hedvig Weiss's (1914-2012) Sakácskönyv a tulélélésért, edited by Szilvia Czingel (2014), a folklorist and musicologist who participated in collecting oral history from survivors for Centropa (on Holocaust trauma and recipes, see further, Vasvári 2016a, 2018, 2019).

Because Király is herself originally from Marosvásárhely/Târgu Mures she started her interviewing there but expanded to a number of other towns in Northern Transylvania and even to Budapest. She learned about the prewar culinary customs of her informants in talking with them about ordinary things, sometimes asking questions that maybe nobody had ever asked them before. By sometimes also cooking for her informants, or along with them, she found that bits of the past about their traumatic Holocaust experiences were suddenly unlocked, as well as about their subsequent struggle of living a post-Holocaust life under the Ceausescu dictatorship. Because most of Király's subjects had been too young to know how to cook before the war, and their mothers did not survive, often they could only try to piece together recipes from scraps of taste memories. The life stories they eventually recounted alongside the recipe talk also were often anecdotal and associative, so Király ended up organizing her work around how memory functions, that is, around the themes to which memories cling, in order to try to bring to life both nostalgic and traumatic memories of her subjects. Király thus collected fragmentary microhistories, along with over two dozen recipes (several in more than one version). The interviews, augmented with appropriate historical, literary, and cultural vignettes - as well as with arresting visual images - form a collective biography of the lives of ten loosely-linked individuals who are representative of their region and era.

Ultimately, Recipes for a New Beginning amounts to something larger than what its title promises, to what Nobel Laureate Svetlana Alexievich - whose own works deal with historical crises through the voices of ordinary people based on interviews - called "emotional chronicles of life," that is, not merely a narrative of events but of the emotions of those involved in them, and also about what is remembered and what is forgotten. Or, as the Holocaust historian Annette Wieviorka has argued, and as Király's work illustrates, the value of Holocaust testimony is not solely as sources of evidence about historical events but should also be understood as a means of transmission of memories of the survivors' own retrospective personal stories, and of themselves as part of history. In this sense, the collection straddles the fields of sociology and folklore, and at the same time it is a contribution to the cultural history of Transylvanian Jewry, all brought together through an evocation of prewar gastronomical nostalgia. Krisztian Nyári, in the Preface to the original Hungarian edition, rightly concludes that the question ultimately raised in Kiraly's study is: what is it that remains today from the shattered culture of Transylvanian Jewry? 
Vasvári, Louise O. "Culinary Nostalgia and Post-Traumatic Stress Disorder: Addenda to Kinga Király's $A z$ újrakezdés receptjei (2019) / Recipes for a New Beginning (2020).” Hungarian Cultural Studies. e-Journal of the American Hungarian Educators Association, Volume 14 (2021): http://ahea.pitt.edu DOI: 10.5195/ahea.2021.437

\section{The Mass Genocide of Transylvanian Jewry: Social Death and the Ecology of Survivor Witnessing}

The main thread of discussion of Király's study is the preservation or, in most cases, the attempted recreation of traditional Jewish recipes, which then leads her informants spontaneously to relate traumatic details about their lives. However, to understand the historical complexity and tragedy of the lives of pre- and postwar Transylvanian Jewry a brief historical sketch is useful. It is a history articulated across the breach of the Holocaust and unique in that it is part of both Hungarian and Romanian history. Through World War I in Transylvania, then part of the Kingdom of Hungary and located along the linguistic and religious fault lines of Central Europe, residents spoke many languages and belonged to many faiths. The area included a large and vibrant population of Jews, many of whom lived in poor Orthodox communities, coexisting with more modern, acculturated and reform Jews, as well as with a strong Zionist movement, whose members believed that Jews would not ever be an integral part of Hungarian society, either in Hungary or in Transylvania.

After World War I, when the multiethnic Kingdom of Hungary was divided by the 1920 Treaty of Trianon, millions of Hungarian speakers were left outside the new Hungarian borders, including those in Transylvania, which was ceded to Romania. During the interwar period the Jews of the area lived in a double-minority status, both among the annexed Hungarian Christian population and within Romanian society. By their historical heritage, cultural roots and language, most Transylvanian Jews remained tied to Hungary, while the socioeconomic and political realities bound them to Romania. During World War II the alliance of Hungary with Nazi Germany allowed it to regain through the 1940 Second Vienna Award a fraction of its territories lost by the Treaty of Trianon, and the northern part of Transylvania came back under Hungarian rule, while the southern area remained part of Romania. After having been under Romanian domination for twenty years many Transylvanian Jews were initially happy to rejoin Hungary. In Romania they had felt they had always lived in domination, often suffering different degrees of legal insecurity regarding citizenship and economic and professional rights, and all the more so in the second half of the 1930s, given the ever-increasing Romanian anti-Semitism of the time. Many Transylvanian Jews also entertained a nostalgia for the Kaiser Franz Joseph era and cherished the illusion that the return to Hungary would denote a return to the "Golden Era" of pre-World War I life.

According to a 1941 census, over 150,000 people of Jewish faith again found themselves under Hungarian rule in Northern Transylvania. However, the subsequent anti-Semitic measures affected 164,052 people in the area, since they applied to all those legally regarded as Jewish according to the anti-Jewish legislation that had been established in Hungary, and which was now enforced even more strictly than in the mother country itself. It is one of the ironies and tragedies of history that the Jews living in the areas allotted to Hungary in the division of Transylvania in 1940 fared far worse than those remaining under Romania. As early as July 1941 murderous rampages were conducted by the Hungarian authorities against some 16,000-18,000 "alien" Jews from all over Hungary who could not prove having a Hungarian citizenship. In August 1941 between 4,000-5000. were deported to Nazi-occupied Kamenets-Podolski in Galicia (today's Ukraine) and were slaughtered in a bloody mass execution. Forced Labor Service programs were started by the Hungarian Army in 1942 and approximately 15,000 Jewish forced laborers of the region were deployed in the first line on the eastern front in the Ukraine, where most perished. Despite all these horrors and despite many other warning signals in the form of political and economic laws and decrees issued by the central and local Hungarian 
Vasvári, Louise O. "Culinary Nostalgia and Post-Traumatic Stress Disorder: Addenda to Kinga Király's $A z$ újrakezdés receptjei (2019) / Recipes for a New Beginning (2020).” Hungarian Cultural Studies. e-Journal of the American Hungarian Educators Association, Volume 14 (2021): http://ahea.pitt.edu DOI: 10.5195/ahea.2021.437

government authorities, the basic confidence of many Hungarian-speaking Jews, especially of those of assimilated background, remained in their belief that the Hungarian state would protect them. Some of the few who perceived the danger tried illegal crossing of the border to Romania, as did the family of Júlia Szilágyi, one of the ten informants in this study, discussed below (on the Holocaust in North Transylvania see further, among others, Gyimesi 2008, Case 2009, Gidó 2009a, Horváth 2012, Egry 2013).

The most brutal and murderous final turn of events in Northern Transylvania commenced, just as it did in the rest of Hungary, with the Nazi occupation of March 19, first with ghettoization and then from May 25 through June 1944, with the bulk of the community deported to Auschwitz, making the area officially Judenrein. Of the total of 165,000 Jews deported, more than ninety percent of whom were of Hungarian culture and language, more than three quarters perished. After 1945 some survivors re-established vestigial Jewish communities, but many others chose to emigrate (see Gidó 2021 on the exact statistics on survivors by age). With the communist takeover in 1948 most of Romanian Jewish life essentially ended, and in the next decade a further 40,000 left for Israel, while many of those who remained assimilated to Romanian or emigrated later to Israel or Hungary. After 1970 Jewish community life virtually ceased to exist in small-town Transylvania. (on the fate of post-Holocaust Jewry in Transylvania see Tibor-Szántó 2004, 2007, 2017, Mayer 2016).

History teacher Gyuri Diamantstein, the son of one of Király's informants, and at seventy-one of the youngest practicing Jews in Târgu Mures, predicted in 2019 that in twenty years there would no longer be a Jewish community in the entire region (McGrath 2019). Ultimately, modern Jewish identity in Transylvania, inasmuch as it still exists, for the most part no longer builds on a religious community but rather on ethnic affinity (Gitelman 2000: 36). Of course, as is also true, as elsewhere, Jews are not needed for anti-Semitism to persist: recently vandals smashed headstones in Târgu Mures, while in nearby Sziget/Sighet others defaced the childhood home of Elie Wiesel with scrawled graffiti, reading "public toilet, anti-Semite pedophile...Nazi Jew lying in hell with Hitler" (McGrath 2019).
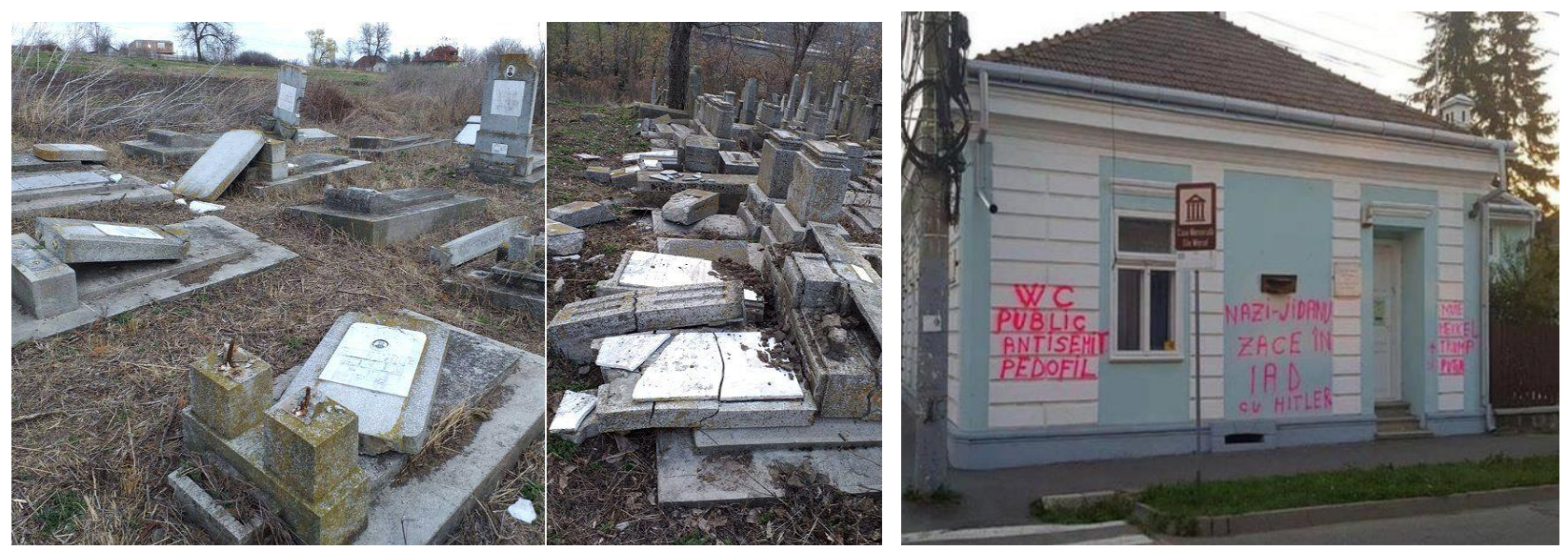

Smashed Headstones in the Jewish Cemetery in Târgu Mures and

Graffiti on Elie Wiesel's Childhood Home in Sziget/Sighet

With such a history to contend with, it is not surprising that unlike the group interviewed by Király, who remained in their homeland, many other survivors, most of whom were teenagers and young adults, chose to start new lives elsewhere. One such example is medical doctor Dora 
Apsan Sorell (1921-2019) - like Wiesel, a native of Sziget and his close neighbor. She was also from an Orthodox family, the youngest of ten children and the only girl. Although most of her family perished her fiancé survived and they chose to remain. She studied medicine in Timisoara but, even with help from a brother abroad, life under Ceausescu was very difficult. In 1961 she and her family were with great difficulty able to leave, first struggling to rebuild a life in Brazil and then finally in the US, where she was able to resume practicing medicine and teach. She and her husband were married sixty-three years and when he died in 2008 she had engraved on her grave marker the number A-7603. She herself died at age ninety-eight in 2019. In her minutely detailed memoir, Tell the Children. Letters to Miriam (1998), Sorell tries to account for the fate of every relative and every friend from Szatmár and also for every camp sister she knew in Auschwitz and in the Weisswasser slave-labor camp. She also describes how it felt on her return to be a postwar survivor of a culture that for her had disappeared:

\begin{abstract}
"What little family we had left after the war did not stay around for long. The old way of life, with its traditions, the Yiddish language, the community, the grandparents and children, were all gone. Only a few young people were around, and even they after brief reunions, often left, searching for new family ties and a new life. Sighet, our birthplace, had become a memory, a reminder of recent tragedies, evoking images of the prewar liveliness superimposed on empty houses, burned synagogues, and deserted streets and schools, devoid of familiar faces. I didn't feel like visiting. I tried instead to run my mind to the present and future."
\end{abstract}

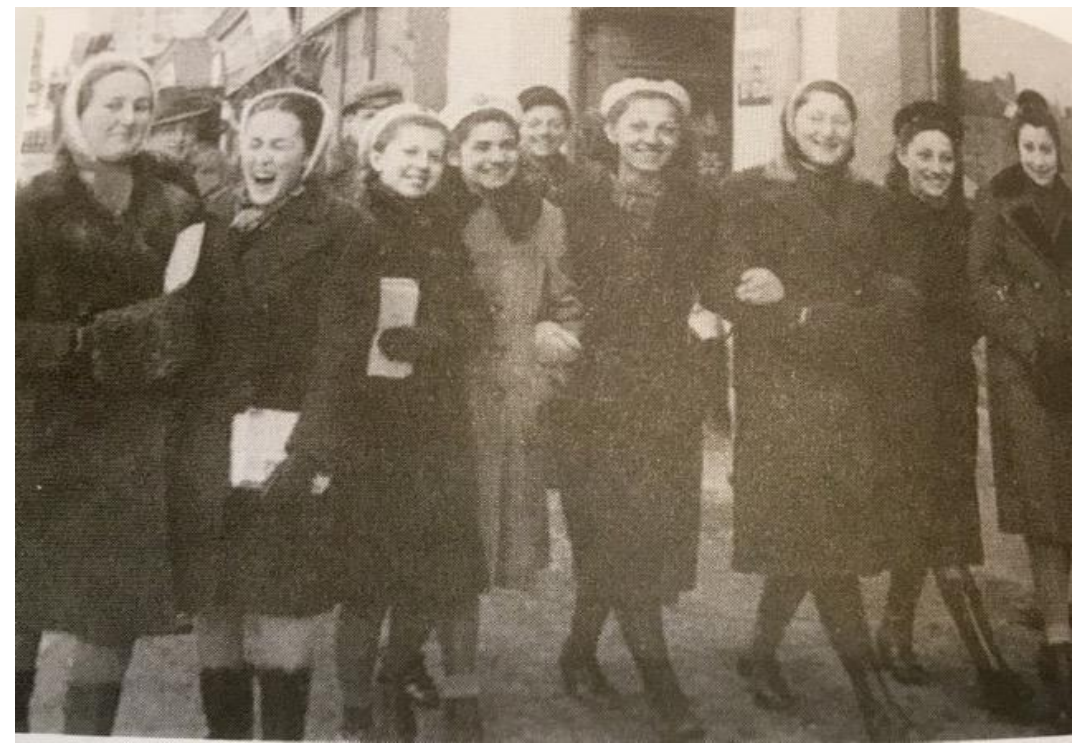

Dora Apsan (fourth from left) with her school friends, Hedi, Hindi, and Olga, on the corso in Szatmár, 1938.

The death of a whole culture that Sorell describes here is what Claudia Card (2010: 237) has called "social death," the ultimate result of genocidal violence, which does not end with the body count of the biological death of mass slaughter. Rather, the destruction continues in the life of the survivors who suffered loss of loved ones and of other relationships, as well as in the destruction of the community and the foundational institutions that had once sustained the victims' cultural belonging and identity. 
Hannah Pollin-Galay in Ecologies of Witnessing: Language, Places, and Holocaust Testimony (2018) has proposed a spatial approach to witnessing, which can reveal the importance of the "ecologies" of testimonies, i.e., the contexts of time, place, and language. She investigates how people remember differently in different languages and geographical contexts and based on different memory worlds of Yiddish, Hebrew, and English. In this sense of "ecological witnessing" Sorell's testimony, written from her multiple emigrations and writing in a new language and new geographic context, necessarily has a different emphasis from that of Király's witnesses, who have lived out their postwar lives in Transylvania.

It is perhaps worthy of mentioning still another, now very old Transylvanian Hungarian survivor, Miriam 'Buba' Weiss Stillman, ninety-five years old, whose postwar life has been so fundamentally different from the life of those who remained behind. She was deported from Kolozsvár and survived with one sister, Icu, with whom she arrived in Vera Cruz, Mexico in 1946, where their eldest sister, Bella had been living with her husband since the 1930s. Bella insisted that they not speak about their past. Miriam Weiss married another Hungarian survivor, and the couple thrived and became pillars of the Mexico City Jewish community. For over a quarter of a century she has been depicting her still vivid traumatic experiences of Auschwitz, Unterluss and Bergen-Belsen through paintings. Perhaps the single most poignant of her paintings is her depiction of herself and her sister, Icu, with shaved heads, standing weak and sad before a barbed-wire fence in Auschwitz.

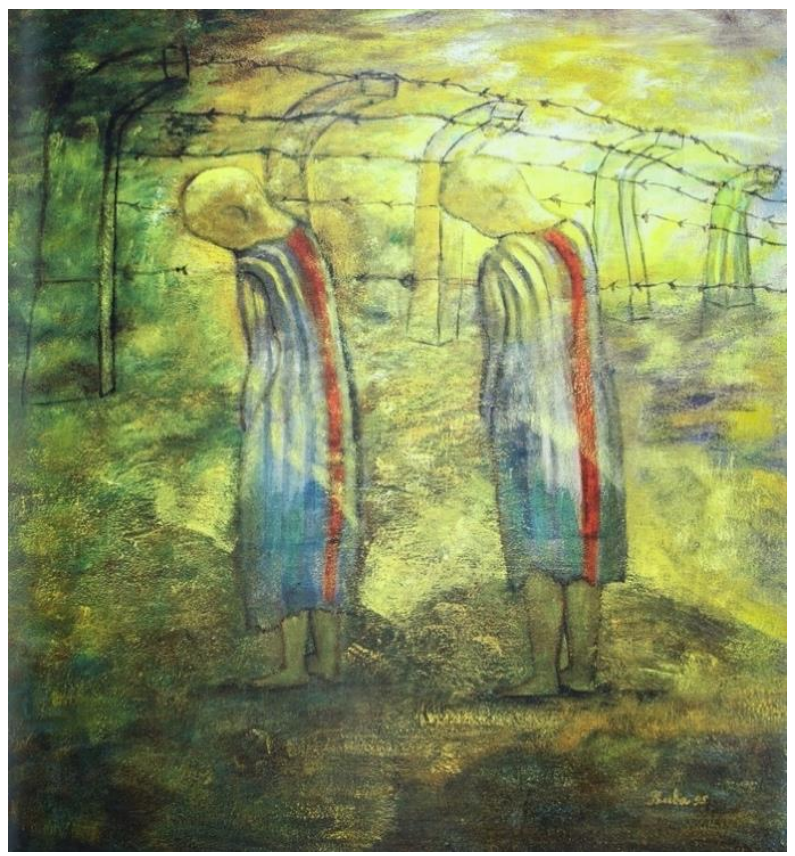

"Buba" Weiss and her Sister Icu in Auschwitz

She also published a memoir in 2015 in Spanish, A11147 tatuado en mi memoria ['Tattooed in My Memory'], where some of her paintings are also reproduced. Now, during the Covid lockdown her husband Lajos (Luis) Stillman, 98, is working on his own memoir (Stephens 2020, 2021). 
Vasvári, Louise O. "Culinary Nostalgia and Post-Traumatic Stress Disorder: Addenda to Kinga Király's $A z$ újrakezdés receptjei (2019) / Recipes for a New Beginning (2020).” Hungarian Cultural Studies. e-Journal of the American Hungarian Educators Association, Volume 14 (2021): http://ahea.pitt.edu DOI: 10.5195/ahea.2021.437

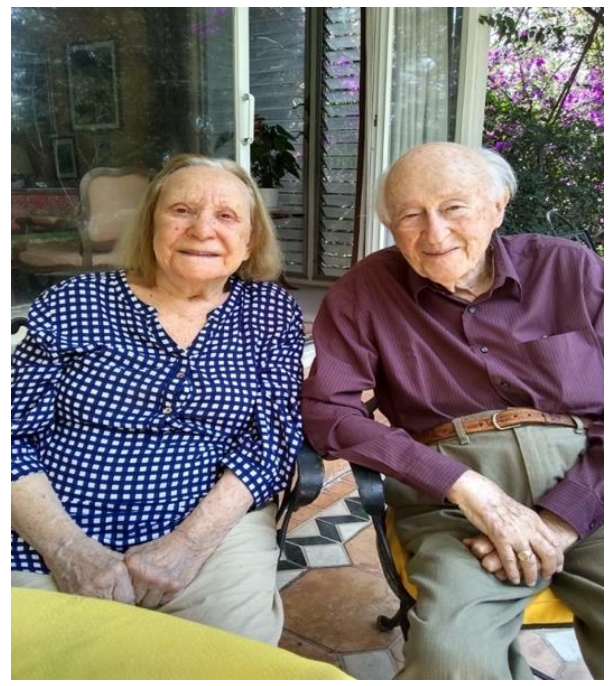

Buba Weiss Stillman from Kolozsvár with her husband Lajos in Mexico City in 2020

\section{Culinary Nostalgia and Post-Traumatic Stress Disorder}

The recollections of Király's subjects - two males and eight females - range from fragmentary to more detailed testimonies, including from two important intellectuals in Transylvanian Jewish life: Lajos 'Lalo’ Erdélyi, (1929-2020), a well-known journalist and photographer, and Julia Szilágyi (1936- ), a professor and essayist from Kolozsvár, who is the youngest member of the group by almost a decade. Both Erdélyi and Szilágyi also authored memoirs worth consulting in conjunction with reading their testimonies in Király's book: Erdélyi wrote Túlélés. Egy fotográfus visszaemlékezése ['Survival. The Memories of a Photographer'] (2006, 2012), and Szilágyi is the author of Álmatlan könyv ['Book of Dreamlessness'] (2014). (Also relevant are Erdelyi's autobiographical "Magyar zsidók Romániában, Erdélyben," and "Sármás, Arad 1944 szeptember," about a massacre within a two-week period of the local Jews by the Hungarian army.) Lajos Erdélyi recounts that his family observed Jewish dietary customs only very superficially, that they even cooked pork at home and that his father, who owned a small perfumery and a photo laboratory on the main street, was in the local Zionist leadership. Yet the family did keep kosher plates for visitors and if the grandparents came to visit they would pretend to be religious.

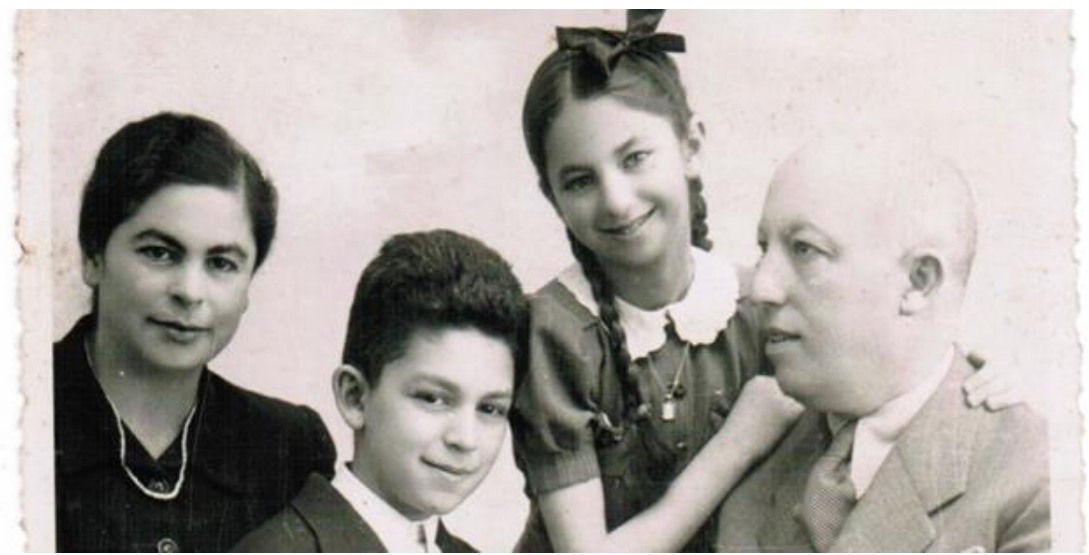

Lajos Erdélyi with his parents and sister before the war 
Erdélyi tells the sad story that his maternal grandmother lived in Palestine and the family were going to leave in 1939. But then his father got a shipment of Caola soap, which was a much sought-after beauty product, at a time when cosmetic soaps were touted as beauty creams are today. An ad for the soap read:

Baeder's CAOLA soap, made from selected, high-quality ingredients, is a totally neutral toilet soap, which with regular use will give your skin a peachy tone and a velvety texture and clean it of all impurities.

['a Baeder CAOLA szappan válogatott nyersanyagokból készült, kiváló minőségü, teljessen neutrális pipereszappan, mely állandó használat esetén az arcot hamvassá és barsonyossá teszi s az arcbőr minden tisztátlanságát eltünteti'].
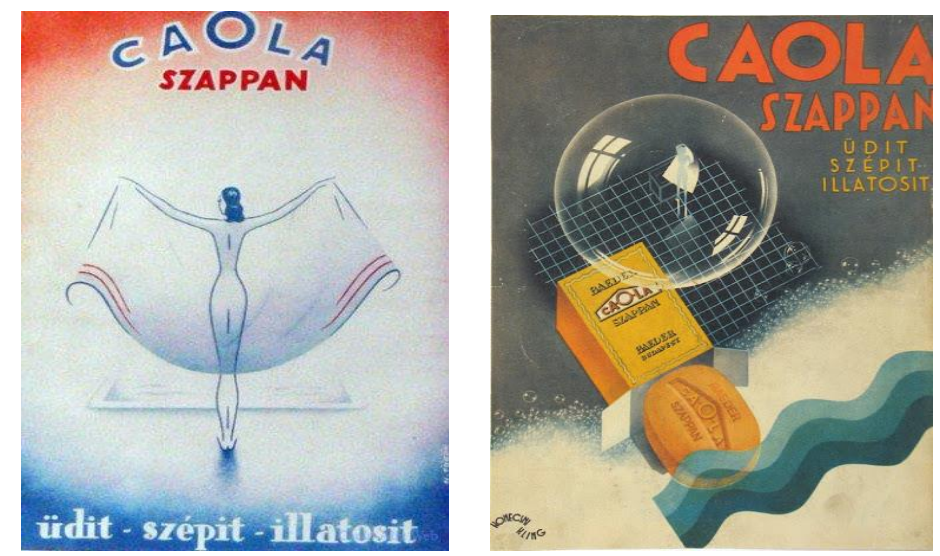

Hungarian Caola Beauty Soap, Manufactured by Hermann Bäder

Erdélyi's father thought he could sell the popular soap by December and then they would emigrate, but of course war broke out in September and the family was trapped. (In reading about the role of the famous Hungarian Caola beauty soap in the Erdélyi's family's destiny, I could not help wondering also about the Holocaust fate of Hermann Bäder and his family, whose major cosmetics manufacturing company was Caola, which he named in 1932 after his daughter, Carola, who as a baby could not say her name correctly. Bäder's wife and co-founder of the company died already in 1936 and Bäder in 1942. I could not find information about the fate of their daughter, but their son István survived the war and restarted another family cosmetics company, Lenor, until 1948, that is, until nationalization.)

Erdélyi's mother and sister were murdered on arrival in Auschwitz, but he and his father eventually returned together to Marosvásárhely from Dörnbau KZ (Silesia). When they got home they were the oldest and the youngest returning survivors; his father donned his son's striped uniform and the local Jewish photographer memorialized their return. After the war Erdélyi's grandmother invited him to Palestine but she did not invite her son-in-law, because she blamed him and the Caola soap for her daughter and granddaughter's death, and so Erdélyi also did not emigrate, although he did eventually move to Budapest. He concludes his testimony saying that although he was totally divorced from a ghetto-like life, he still did keep his sajátos erdélyi magyar zsidó identitasát ['particular Transylvanian Hungarian-Jewish identity']. 
Vasvári, Louise O. "Culinary Nostalgia and Post-Traumatic Stress Disorder: Addenda to Kinga Király's $A z$ újrakezdés receptjei (2019) / Recipes for a New Beginning (2020).” Hungarian Cultural Studies. e-Journal of the American Hungarian Educators Association, Volume 14 (2021): http://ahea.pitt.edu DOI: 10.5195/ahea.2021.437

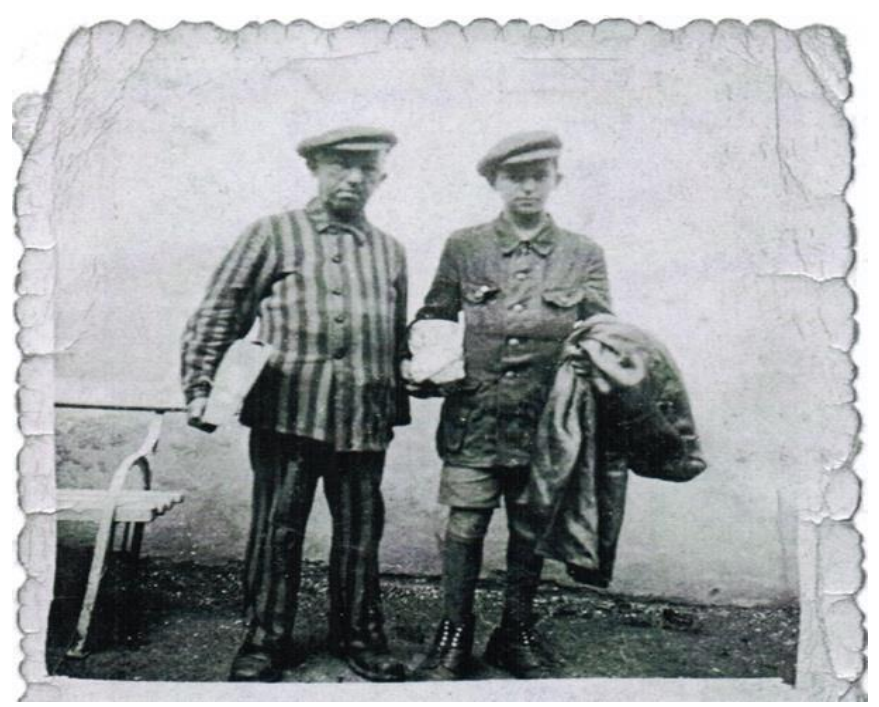

Emil and Lajos Erdélyi's arrival home in 1945

In Júlia Szilágyi's beautifully-written memoir, which she calls an emlékezetbe zárt forditott nevelödési történet ['a reverse bildungsroman enclosed in memories'], she makes clear that some of our memories are not ours at all but were told to us. In part of her book she presents such a family chronicle from heard stories, in which she lovingly, yet with irony manages to bring to life each of her relatives, from the beautiful young aunt she knew only through a striking photo (reproduced in the book), who died from the Spanish flu, to her grandiose eighty-six-yearold grandfather, who perished in Auschwitz with his younger fourth wife. Many family anecdotes Szilágyi recounts resonate with deep historical meaning, such as the one about her father, who shouted in a government office that his father's name was not Lupu ['Wolf' in Romanian], as government documents had subsequently falsified, but Szilágyi Farkas!

Szilágyi's personal recollections of her wartime childhood are that of a child-eyed observer but not in the least prettified. She was not yet eight when deportation started. Like Erdélyi, she also recounts that her secular mother did not keep kosher, which became a big problem with her mother-in-law when they were forced to live together during the war. She also recounts being on a bus as a small child, on her way to an urgent dentist appointment with an aunt who was married to a gentile and not required to wear a star. This aunt then removed the child's star, but a woman who recognizes the little girl called out: Julika, szereted a csoletet? ['Julika, dot you like Cholent?'] to let her know she had no right to be on the bus, which the little girl did not understand at the time. She also couldn't understand why her two aunts married to gentiles had different colored ration cards than her family, but eventually came to realize that mixed marriages were a place of safety because there was no way to hide without help from the majority population. Family connections also helped her family survive by escaping to Bucharest. At the end of the war, when she and her mother return to Kolozsvár, in the courtyard by her grandmother's home she finds a different skinny little girl on her bike and wearing her checked raincoat. The little girl's mother stares at them as if they were revenants and tries to say she was not a thief, and that they did not know anything: mi csak úgy kaptuk ['it was just given to us']. She tried to unbutton the little girl's raincoat, while the girl protests, screaming, and meanwhile little Julika is also crying and demanding back what belonged to her. Only then did she wonder: where is grandmother Vilma? 
Vasvári, Louise O. "Culinary Nostalgia and Post-Traumatic Stress Disorder: Addenda to Kinga Király's $A z$ újrakezdés receptjei (2019) / Recipes for a New Beginning (2020).” Hungarian Cultural Studies. e-Journal of the American Hungarian Educators Association, Volume 14 (2021): http://ahea.pitt.edu DOI: 10.5195/ahea.2021.437

Szilágyi continues her story only to the middle of the nineteen-forties. We know, but not from her book, that the Securitate had a file on her as a nationalist and cosmopolitan, and she was not allowed to teach in Kolozsvár until after 1990, where she become a renowned professor to generations of students. She was not moved to write about her family's life until an unpleasant incident occurred to her in 1984 on the fortieth anniversary of deportation, but her decision to do so was governed by her understanding that ultimately the loss of a culture depends on the will of its last survivors:

Whoever wants to eradicate a culture, in another or in himself, must erase the memories.

Not the textbooks. Not the legends that have become a treasure trove. No. The most personal, the memories of children....

['Aki fel akar számolni egy kultúrát, másban vagy önmagában - az emlékeket kell kiirtania. Nem a tankönyveket. Nem a kőzkincssé vált legendákat. Nem. A legszemélyesebbet, a gyermek emlékeit.... '] (32)

And so Szilágyi ends her work with the lines, Akarom hogy halottaim túléljenek ['I want my forebearers/dead to survive']

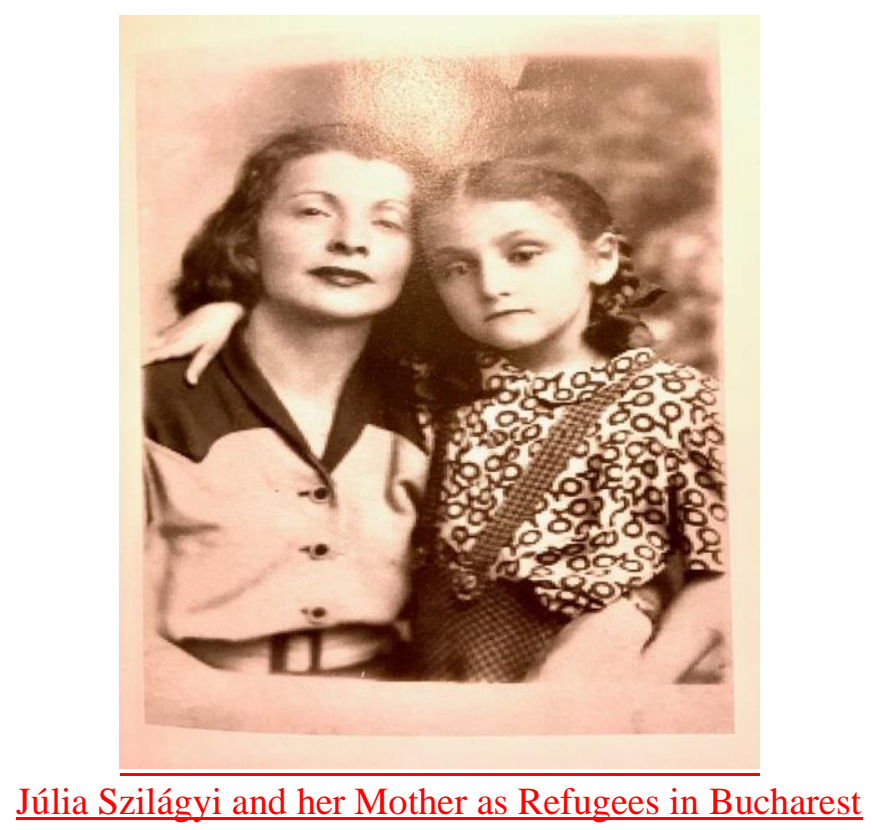

Also worthy of special mention among Király's subjects is Zsuzsa Diamantstein, who admits she is not much of a cook and merely discusses Purim pastries her mother used to prepare, flodni, hamantaschen and kindli, so it is Király who bakes her flodni, to see if it awakened taste memories of what her mother used to bake. Along with all the others, Zsuzsa has a Hungarian-speaking identity and she recounts how her mother prayed in the synagogue not with a Hebrew prayer book but with a Hungarian one, called Miriam, written by the rabbi of Kecskemét. She also discusses her uncle Sándor Riegelhaupt, who was in the timber business, the main industry in Gyergyószentmiklós, but he was also an extraordinary amateur photographer. Given my own interest in vintage photography I tried to find out more about him 
and learned that he was indeed distinguished, mentioned a number of times in interwar papers. He survived the Holocaust because in 1978 and 1979 he is mentioned in the Romanian Hungarian papers of Homonai magyar szó, Elöre, and Új élet as someone who possesses thousands of photos from the fehér-fekete múlt ['black and white past'] (there are also more details of the family with photos, available through interviews in 2004 in Centropa, https://www.centropa.org/hu/biography/diamantstein-zsuzsa, and Diamantstein 2019)

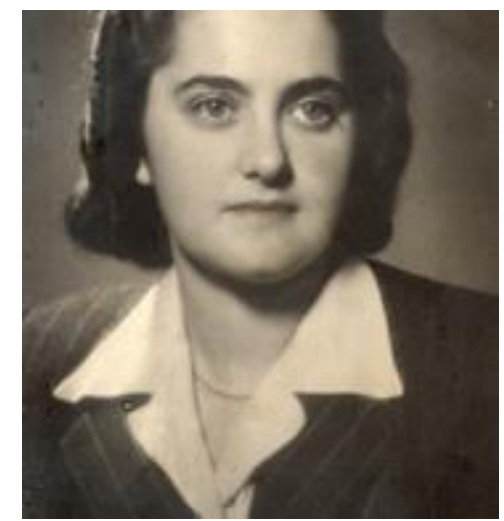

Zsuzsa Diamantstein on her twentieth birthday in 1942

Of special interest is the memoir, Szurika, Éva lánya (2018) by Sara Tabák Székely (1936-2011), who was already deceased at the time of Király's research, or she would have surely been another of her subjects. Sára Székely, or Sárika/Szurika, was the cousin of Leopold Kárpelesz, the other one of Király's two male subjects. Kárpelesz relates how Szurika knew a huge amount about the contemporary customs and everyday lives of poor Jewish families. Júlia Szilágyi, who wrote the blurb for Székely's book, also praised her highly. The memoir, besides being an unusual Holocaust story, is a unique evocation of the culinary folk custom of her own poor Orthodox family and of the population of timber workers of Gyergyószentmiklos/ Gheorgheni, a very traditional Transylvanian Jewish community. Székely's book has unfortunately had no significant reception in Hungary, but parts of it can be accessed online through Centropa (https://www.centropa.org/hu/search/site/Szekely\%2520Szurika). Also available is a charming 2007 video of the author visiting with a gentile childhood friend in their hometown, "Zsidó emlékek Gyergyószentmiklósrol"

(https://www.youtube.com/watch?v=FsuSqUe2HBk). 


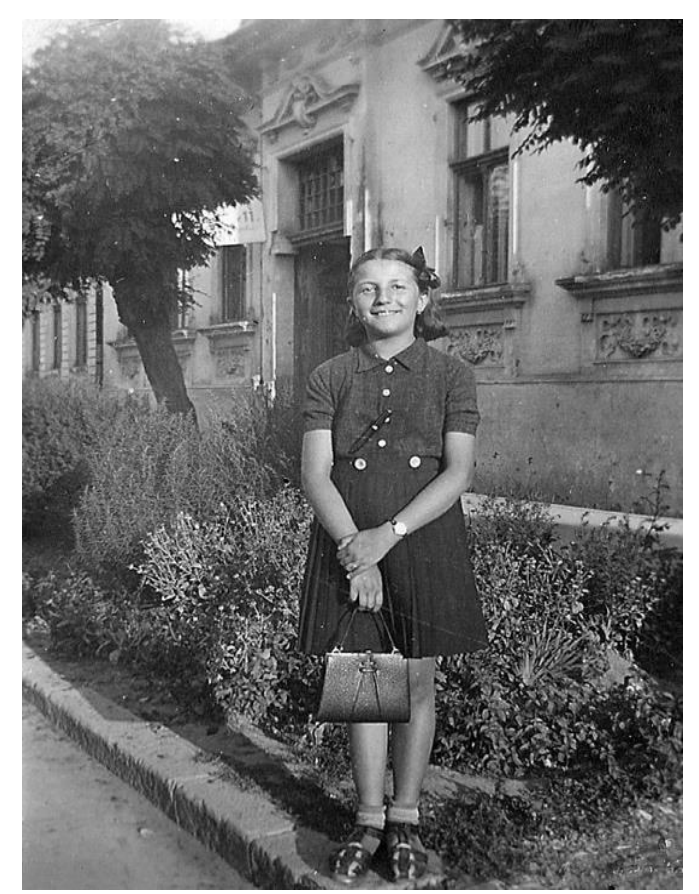

Szurika Tabák in 1939, posing with a new red handbag in Marosvásárhely (Andrea-Julika Ghita)

\section{Lost Prewar Transylvanian Jewish Food Culture: From Csolent to Falshe Fish}

The study of the prewar Jewish food culture of provincial Hungarian-speaking Jews is especially dire, given the virtual destruction of its population, including of the adult and older women who were the primary transmitters. András Körner, in his A magyar zsidó konyha: kulturtörténet 77 autentikus recepttel ['Hungarian Jewish Cooking: A Cultural History with 77 Authentic Recipes'] (2017), dealt with Jewish foodways from the mid-nineteenth century only until 1945, stating that Hungarian Jewish society and its cooking changed completely after the war. Several of the subjects in Király's book talk about force feeding geese to sell, about the importance of goose fat, and about goose liver as the greatest delicacy, which the poorer families seldom got to eat themselves because well-to-do families would pay well for the fattened liver. The best description of the process comes not from any of Király's informants but from Szurika Székely's memoir, who describes how the factory owner and employees would come to her mother before Easter and reserve it:

Aunty Éva, if you don't need the goose liver, we'll buy it." But sometimes my mother had [raised] twogeese, and then we kept one of the livers. That was the most delicious dish.

['“Éva néni, ha nem kell a libamáj, mi megvesszük.” De volt úgy is hogy két ludja volt édesanyámnak, akkor az egyik máj nekünk maradt. Ez volt a legfinobabb étel'].

Among the recipes discussed by Király's ten informants, the main emphasis is on holiday dishes. Naturally, cholent - csolet in Transylvania - is mentioned by several, with disagreement on details of its preparation, which gives away the level of poverty in poorer families, where it is comprised of brisket and beans and pearl barley, with the kugel/kugli ['potato or cornmeal cake'] cooked in it. Families that had geese might add smoked goose, stuffed goose neck and eggs, and 
Vasvári, Louise O. "Culinary Nostalgia and Post-Traumatic Stress Disorder: Addenda to Kinga Király's $A z$ újrakezdés receptjei (2019) / Recipes for a New Beginning (2020).” Hungarian Cultural Studies. e-Journal of the American Hungarian Educators Association, Volume 14 (2021): http://ahea.pitt.edu DOI: 10.5195/ahea.2021.437

the kugel might be cooked separately, while richer household might also leave out the barley. Lajos Erdélyi explains that in his house kugel was cooked in the cholent, then taken out and sliced like salami. Aranka "Goldi" Salamon recounts a recipe where the beans are presoaked and pearl barley, which they call buris, is added, and in her family kugel, made from grated potatoes, was baked separately and eaten after the cholent. Leopold "Rudi" Kárpeles says that in his family's version the beans were not soaked in advance and that the kugel was baked inside the beans, while Zsuzsa Diamantstein goes into discussion of the cholent her mother made with fatty brisket and supposedly put in hard boiled eggs among the beans. (It was actually always uncooked eggs that were put into the pot and it is only today in restaurants that the dish might merely be decorated with hard boiled eggs). While in Bukovina, where Anni, Erdélyi's wife was from, cholent was more like soup, she didn't prepare it that way because her husband did not like it. Again, by far the best description of the weekly cholent preparation is in Szurika Székely's memoir, where she recounts that every week she worried that the dish would come back watery from the bakery, where it had cooked all night:

We always had cholent for lunch; Mum would make it on Friday. It was a one-pot meal, made from white beans and pinto beans cooked with barley and fatty beef. It was seasoned with salt and pepper and put in an earthenware cooking pot with just enough cold water to cover, with a potato or cornmeal cake on top. That's what we called kugel. Before the lamps were lit, the children would take the cholent to the hot stove, and using a wooden paddle the pots were placed inside in order of arrival. The stove was closed and the pots were left there until Saturday noon, when the children would take the piping hot pots back home. On the way home we'd try to guess how well the cholent would turn out: Would it be soupy? Would the top be burnt? Or would it be thick and creamy? It all depended on where it had been placed in the stove. There was a saying that cholent is like marriage: Sometimes it works out, sometimes it doesn't. It's a delicious meal, keeps for a long time and cools slowly, so there's no need to light a fire to reheat it' (Székely 2008: 24-25).

An interesting dish discussed by several informants is falcs hal ['false fish'], called in various sources falshe/faltche fis[c]h or b[a]ilik fish ['cheap fish']. Rudi Kárpeles recounts how he would sometimes catch fish for the Sabbath dinner but if he did not then his mother would make falshe fish, but he couldn't remember how it was made. Király really wanted to cook the recipe for him but no one else knew how to make the recipe either. The dish is actually an imitation of the Sabbath gefilte fis, prepared from poached ground chicken breast when fresh carp was either not available or unaffordable. While this dish, today virtually unknown, clearly could not have tasted like fish, it was prepared and looked the same way, and curiously it is recalled fondly also by others. For example, Zsuzsanna Fischer Spiro (1925- ), another rural Hungarian Jewish girl and camp survivor, from the small village of Tornyospalca, located in the Northeast Great Plains of Hungary, recalls in her memoir a happy prewar family life and a provincial culture that was later erased. Although she was from an Orthodox family and she devotes special attention to the description of Jewish holidays, in her recollections it is only holiday meals that serve as a means of transmitting Jewish customs and heritage, rather than any mention of specific religious observance. She mentions that among the holiday foods that she particularly liked as a child was a dish she could not name but could only describe as chicken that tasted like fish (Vasvári 2016). 
Király herself had tasted falshe fish only in the Klezmer Hois, a kitschy restaurant situated in an old building that had once housed a ritual bath in Krakow's phantom Jewish Town, where one can find a kosher meal and klezmer music but is unlikely to find a living Jew (Saxonberg and Waligorska n.d.). While recipes can vary it is doubtful that the recipe Király created is how it would have been generally prepared in Transylvania, where it was made with ground chicken. I offer here the elegant recipe of Ilona Kellner/Elena Kalina, thanks to her daughter Eva Moreimi, who wrote a memoir, Hidden Recipes: A Holocaust Memoir (2019). She wrote about her parents' survival and about how her mother secretly collected and wrote down some six hundred recipes in the munitions factory where she was a slave laborer, adding when she could the name of the women who had provided the recipe, although often only the first name. Ica hid the recipes in a hidden pouch she had cut from the lining of her oversize coat. She once even ran into a burning building that was being bombed by the Allies to rescue them. Then they were with her on the death march and traveled with her from Europe to the U.S., where she regularly still cooked from them. Eva Moreimi graciously provided me with her mother's recipe:

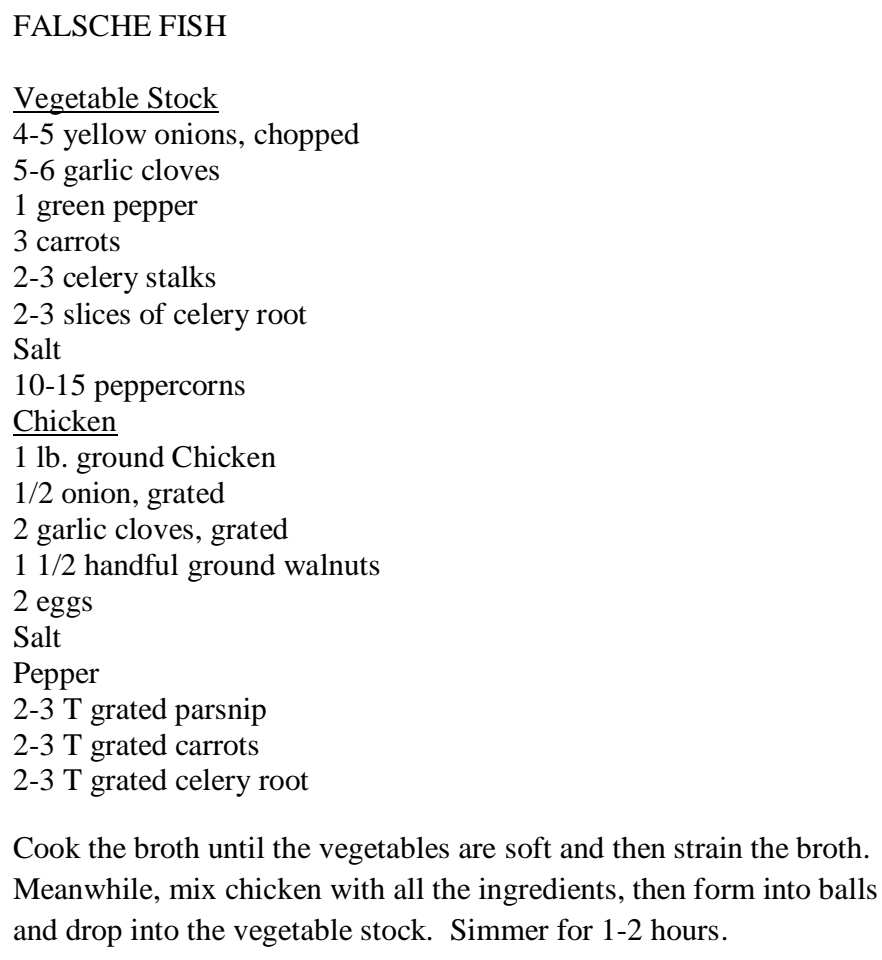

\section{Recipes for a New Beginning as a Culinary Memorial Book of Transylvanian Jewry}

Király's collection can be considered as a continuation of the tradition of the memorial or yizkor ['remembrance'] books, although with an emphasis on culinary remembrance. Already in the interwar period there existed yizkor books in response to extreme personal and communal losses suffered by Jewish communities; these earlier collections then established a pattern for the post-Holocaust era ones, which are collaboratively-produced written monuments to commemorate the life and death of a place and its people. They typically follow a four-part structure, from describing prewar Yiddish village traditions from before the Nazi period, during 
Vasvári, Louise O. "Culinary Nostalgia and Post-Traumatic Stress Disorder: Addenda to Kinga Király's $A z$ újrakezdés receptjei (2019) / Recipes for a New Beginning (2020).” Hungarian Cultural Studies. e-Journal of the American Hungarian Educators Association, Volume 14 (2021): http://ahea.pitt.edu DOI: 10.5195/ahea.2021.437

the Holocaust (a part which, surprisingly, or not, is sometimes the thinnest in the book), the return after the war (and continuing anti-Semitism); migration, and a final necrology. Holocaust memorial books typically contain lamentations, liturgical portions, memoirs, testimonies, tales, community documents, illustrative materials, poems, and other ephemera. The earliest memorial books in the first decade after World War II came out of numerous countries, but from the 1950 most appeared in Israel, usually in Yiddish and/or English and Hebrew, with their peak years in 1960s and 1970s, and they are still appearing up to the very end of the twentieth century and occasionally to the present (Horowitz 2011; and see Schatteles 2021 for an excellent most recent such work on Temesvár).

Culinary nostalgia in the second and third generation, much more prevalent in diasporic memories, start with family attempts and then move to organized ones, where cookbooks are a peculiar subcategory of memorial books. Because culinary nostalgia often manages immigrant and diasporic memories, distanced geographically and temporally from childhood homes, where food gives nostalgic restructuring of home displacement, it is therefore not surprising that of late there also exists a subcategory of Memorial Books, which link the Holocaust with culinary Jewish memories. Two such examples are The Holocaust Survivor Cookbook: Collected from Around the World (2007), by Joanne Caras, a United States-born daughter of survivors, which contains untested recipes as she received them, with one hundred stories, and Recipes

Remembered: A Celebration of Survival (2011), by June Feiss Hersch, which provides readers with a collection of eighty tested and altered survivor recipes, along with their family stories. Kiraly's collection, however, stands unique among nostalgia cookbooks because she compiled her material not from survivors or their children living in emigration but from those very few and now disappearing survivors who stayed in their Transylvanian home.

Yizkor books traditionally end with a necrology of a shattered past of a whole community. Just before Király finished the manuscript of her book she received news of the death of Helena Kain, Lea néni, perhaps the most beloved of her subjects, who previous to meeting Király had not talked for seventy-four years about her lager experiences. The book ends with a kaddish said at her funeral in the Neolog cemetery in Szatmár. Although living in Szatmár Lea néni could not obtain kosher meat, Király lauds her as someone who kept her beliefs until the very end, as well as kept a kosher kitchen Szatmár falu szélén ['living on the outskirts of Szatmár].

\section{Jewish Cemeteries and the Social Death of Jewish Tradition in Transylvania}

Since the original Hungarian publication of Király's book not only Lea néni but also another of Király's subjects, Lajos "Lalo" Erdélyi passed away in his ninety-first year. It is worth reading the brief obituary by Attila Vári (2020), who recounts how they went together on an outing, where Lalo cooked on an open fire fried trout rolled in polenta flour, along with tejelögomba ['milk cap mushrooms'] that he had foraged, but the pleasant outing was marred by a sight - what at first looked like a hanged man dangling from a tree but turned out to be a scarecrow - which brought forth shattering traumatic Holocaust memories for Erdélyi, who had seen many rows of such victims through the opening in the cattle car on the way to Auschwitz . Lalo was a fascinating personality, who did much for preserving through both his writing and photo-journalism memories of lost Jewish life in Transylvania. He pioneered the post-Holocaust documentation of almost ninety Jewish cemeteries, where he photographed outstanding remnants of the folk art of tombstone carving, and discussed gravestone styles and burial practices and the symbolism used in carvings and epitaphs in his Régi zsidó temetök müvészete ['Old Jewish 
Vasvári, Louise O. "Culinary Nostalgia and Post-Traumatic Stress Disorder: Addenda to Kinga Király's $A z$ újrakezdés receptjei (2019) / Recipes for a New Beginning (2020)." Hungarian Cultural Studies. e-Journal of the American Hungarian Educators Association, Volume 14 (2021): http://ahea.pitt.edu DOI: 10.5195/ahea.2021.437

Cemeteries'] (1980; cf. also Kiss 2014; Balogh and Bányai 2020). In his cemetery photos and descriptions Erdély literally documented the death of Jewish life in Transylvania, concluding that with a few rare exceptions, the cemeteries in Central and Eastern Europe are at death's door.

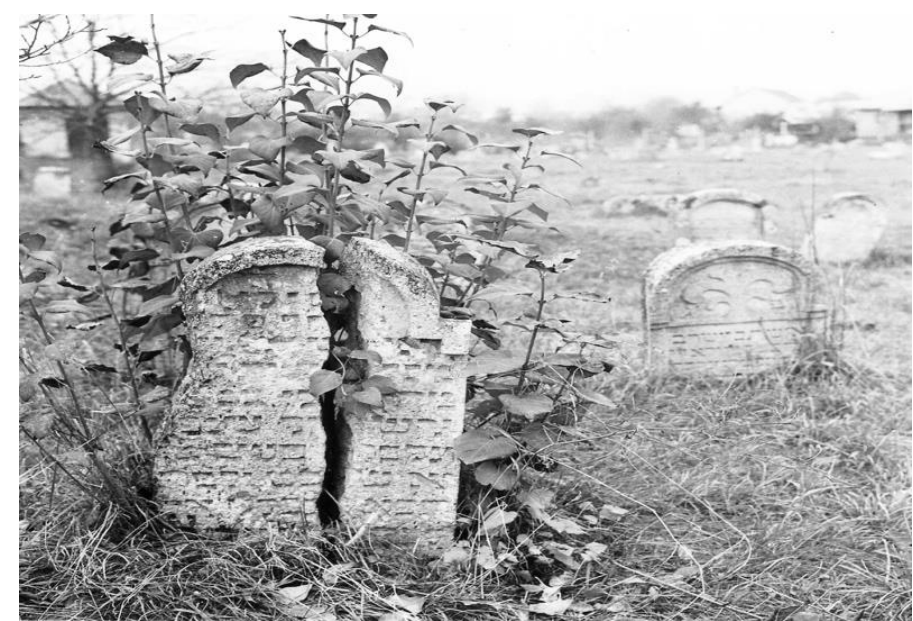

Shattered Tombstones (Erdélyi, Régi zsidó temetők müvészete, 1980)

\section{Works Cited}

Balogh István \& Bányai Viktoria. 2020. “A Magyarországi zsidó temetők kutatása és védelme." Regio 28.3: 24-38

Caras, Joanna. 2007. The Holocaust Survivor Cookbook: Collected from Around the World. N.p: Carras and Associates.

Card, Claudia. 2010. Confronting Evils: Terrorism, Torture, Genocide. Cambridge: Cambridge UP.

Case, Holly. 2006. "The Holocaust and the Transylvanian Question in the Twentieth Century," The Holocaust in Hungary: Sixty Years Later. Eds. Randolph L. Braham and Brewster S. Chamberlin. Boulder; Social Science Monographs: 17-40.

Czingel, Szilvia, ed. 2014. Sakácskönyv a tulélélésért. Lichtenworth, 1944-1945. Budapest: Corvina.

Diamantstein, Zsuzsa. 2019. “Aztán elvitték” - interju az Auschwitzot megjárt marosvásárhelyi Diamanstein Zsuzsával." Nethuszar 09.26.2019 https://nethuszar.ro/zsido-erdely/aztanelvittek-interju-az-auschwitzot-megjart-marosvasarhelyi-diamantstein-zsuzsaval/

Egry, Gábor. 2013. "Negotiating the Straits. Changing Borders, Changing Rules and Practices of Ethnicity and Loyalty in Romania After 1918." Hungarian Historical Review 2.3: 449476.

Erdélyi, Lajos. 2006. Túlélés. Egy fotográfus visszaemlékezése, javitott és bövitett kiadás. Budapest: Zachor Alapitvány, 2012; trans. Survival: A Photographer Remembers, 2014. Erdélyi, Lajos. 2000. “Magyar zsidók Romániában, Erdélyben.” Múlt és Jövő 2000.1: 25-46. Erdélyi, Lajos. 2000 "Sármás, Arad 1944 szeptember." Múlt és Jövő 2004:4: 334-41. Erdélyi, Lajos. 1980. Régi zsidó temetôk müvészete. Bucharest: Kriterion Könyvkiadó; expanded Hungarian-English edition, Az élök háza/The House of the Living. Budapest: Héttorony Könyvkiadó, 2012. 
Vasvári, Louise O. "Culinary Nostalgia and Post-Traumatic Stress Disorder: Addenda to Kinga Király's $A z$ újrakezdés receptjei (2019) / Recipes for a New Beginning (2020).” Hungarian Cultural Studies. e-Journal of the American Hungarian Educators Association, Volume 14 (2021): http://ahea.pitt.edu DOI: 10.5195/ahea.2021.437

Gidó, Attila. 2021. "Lista húszezer észak-erdélyi túlélőröl.” Szombat 01.26.

Gidó, Attila. 2015. "The Hungarian Bureaucracy and the Administrative Costs of the Holocaust in Northern Transylvania." Hungarian Historical Review 4.3: 641-672.

Gidó, Attila. 2009a. "On Transylvanian Jews. An Outline of Common History." Working Papers in Romanian Minority Studies 17: n.p.

Gidó, Attila. 2009b. Uton: Erdélyi zsidó társadalom és nemzetépitési kisérletek (1918-1940) Csikszerda: Pro-Print Könyvkiadó.

Gitelman, Zvi. 2000. "Reconstructing Jewish Communities and Jewish Identities in PostCommunist East Central Europe." Jewish Studies at the Central European University. 3550. http://web.ceu.hu/jewishstudies/pdf/01_gitelman.pdf

Gyimesi, Eva Cs. 2008. "Erdély és a holokauszt.” Beszélő 13.3 http://beszelo.c3.hu/cikkek/erdely-es-a-holokauszt

Hersch, Judy Feiss. 2011. Recipes Remembered: A Celebration of Survival: Beachwood, OH: Museum of Jewish Heritage.

Horváth, Franz Sz. 2012. "Ethnic Policies, Social Compensation, and Economic Reparations: The Holocaust in Northern Transylvania." East Central Europe 39: 101-136.

Horowitz, Rosemary. 2011. Memorial Books of Eastern European Jewry: Essays in the History and Meanings of Yizkor Volumes. Jefferson, N.C.: McFarland.

Király, Kinga Júlia. 2019. Az újrakezdés receptjei, Erdélyi zsidó történetek életröl, éhségröl és reménységröl ['Recipes of a New Beginning, Transylvanian Stories About Life, Hunger, and Hope']. Târgu Mures: Mentor 2019; Recipes for a New Beginning, Transylvanian Jewish Stories of Life, Hunger and Hope. Trans. Rachel Hideg. Frankfurt am Main: CEEOLPress, 2020.

Kiss, Erika Márta. 2014. Erdélyi zsidó közösségei a kezdetektöl napjainkig a temetök tükrében. PhD Diss. Budapest: Országos Rabbiképző-Zsidó Egyetem.

Koerner/Körner, András. 2017. A magyar zsidó konyha: kulturtörténet 77 autentikus recepttel. Budapest: Corvina; trans. Jewish Cuisine in Hungary: A Cultural History with 83 Authentic Recipes. Budapest: Central European P, 2019.

Mayer, Gabriel 2016. "Where Are the Jews of Post-Holocaust Cluj (Kolozsvár)." International Journal of Social Science Studies 4.9: 69-82.

McGrath, Stephen. 2019. "Anti-Semitism Threatens Romania's Fragile Jewish Community." BBC News https://www.bbc.com/news/world-europe-47865369

Moreimi, Eva. 2019. Hidden Recipes: A Holocaust Memoir. Minneapolis: Secondgen Press.

Pollin-Galay, Hannah. 2018. Ecologies of Witnessing: Language, Places, and Holocaust Testimony. New Haven: Yale UP.

Saxonberg, Steven and Magdalena Waligorska. n.d. "Klezmer in Krakow: Kitsch or Catharsis for Poles?" https://www.press.uillinois.edu/journals/ethno/docs/sample_coded_article.pdf

Schatteles, Tibor. 2020. A temesvári zsidoság történelmi távolatképe. Budapest: Tom Lántos I ntézet/ Múlt és Jövő.

Sorell, Dora Apsan. 1998. Tell the Children. Letters to Miriam. Berkeley CA: Sighet Publications [Private].

Stephens, Bret. 2021. "Can We Really Picture Auschwitz?" New York Times https://www.nytimes.com/2021/04/02/opinion/holocaust-

survivor.html?campaign_id=39\&emc=edit_ty_20210402\&instance_id=28770\&nl=opiniontoday@i_id=72667413\&segment_id=54746\&te=1\&user_id=7fc5ecffdeaf3d01789c06dacf0a124 $\underline{1}$ 
Vasvári, Louise O. "Culinary Nostalgia and Post-Traumatic Stress Disorder: Addenda to Kinga Király's $A z$ újrakezdés receptjei (2019) / Recipes for a New Beginning (2020).” Hungarian Cultural Studies. e-Journal of the American Hungarian Educators Association, Volume 14 (2021): http://ahea.pitt.edu DOI: 10.5195/ahea.2021.437

Stephens, Bret. 2020. "You Will Not Live to See Your Next Birthday." New York Times https://www.nytimes.com/2020/05/08/opinion/holocaust-survivor.html?searchResultPosition=1 Stillman, Buba Weiss. 2015. A11147 tatuado en mi memoria [A11147 Tattooed in My Memory']. Mexico: n.p.

Székely, Sara. 2007. Szurika, Eva lánya. Kluj: Mega Kiadó; Budapest: Napvilág, 2008. Szilágyi, Júlia. 2014. Álmatlan könyv. Kolozsvár: Korunk.

Tibori-Szabó, Zoltán. 2017 "Memorialization of the Holocaust in Transylvania During the Early Post-War Period.” Southeast European and Black Sea Studies 17.2: 281-299.

Tibori-Szabó, Zoltán 2007. Arnyékos oldal. Zsidó identitástudat Erdélyben a holokauszt után. Kolozsvár: Koinonia.

Tibori-Szabó, Zoltán. 2004. “Az erdelyi közösség sorsa a második világhaborut követő időszakban (1945-1949).” Korunk 8.15: 78-85.

Vasvári, Louise O. 2019. "A Proust jelenség és a nök többgeneraciós táplálkozási élettörténetirása mint a holokauszt traumairodalma.” Litera 45.3 (2019): 248-261: https://ojs3.mtak.hu/index.php/literatura/issue/view/222/102

Vasvári, Louise O. 2018. "Identity and Intergenerational Remembrance Through Traumatic Culinary Nostalgia: Three Generations of Hungarians of Jewish Origin.” Hungarian Cultural Studies 11 (2018): 57-77: https://ahea.pitt.edu/ojs/index.php/ahea/article/view/322/630

Vasvári, Louise O. 2016a. "Nem és emlékezet a táplálkozási élettörténetirásokban a holokauszt idején és után.” Múlt és Jövő 2016.4: 104-140.

Vasvári, Louise O. 2016b. "Introduction" to Zsuzsanna Fischer Spiro In Fragile Moments. Eva Shainblum. The Last Time. The Azrieli Series of Holocaust Survivor Memoirs. Toronto: The Azrieli Foundation, 2016.

Vári , Attila. 2020. “Ijesztő napunk.” Múlt és Jövő 2020.4: 1-3. 